5. On the Due Administration of Bloodletting.

6. On a Hydrocephaloid Affection of Children, arising from Exhaustion.

7. A New Mode of Treating Nævus.

8. An Experimental Investigation of the Effects of Loss of Blood.

9. Memoirs on the Principles of Pathology in the Nervous System; and especially

10. On the Condition of the Muscular Irritability in Paralytic Limbs, \&c., \&c.

IV.-Papers read before the Royal Society.

1. On the Anatomy and Physiology of the Minute and Capillary Vessels.

2. On the Inverse Ratio between Respiration and Irritability, in the Animal Kingdom.

3. On Hibernation.

4. On the Reflex Function of the Medulla Oblongata and Medulla Spinalis.

5. On the Medulla Oblongata and Medulla Spinalis, and the Excito-Motor System of Nerves.

6. On the Relation of Galvanism and the Nervous and Muscular Tissues.

V.-Separate Works.

1. The Principles of Diagnosis.

2. The Effects of Irritation and Exhaustion after Parturition, Abortion, \&c.

3. Commentaries on the Diseases of Females.

4. An Experimental Essay on the Circulation of the Blood.

5. Observations on Bloodletting, founded on Researches on the Morbid and Curative Effects of Loss of Blood.

6. Lectures on the Nervous System.

7. Memoirs on the Nervous System : First, Second, and Third, or "New" Memoir.

8. On the Derangements and Diseases of the Nervous System.

9. Synopsis of the Diastaltic Nervous System.

We are compelled to omit the titles of the series of papers by Dr M. Hall which have during so many years appeared in our own pages; but we must not fail to recal to the memory of our readers, the recent papers " $O n$ THE NECK as a Medical Region, and on the Class of Paroxysmal Diseases," containing an application of Dr. M. Hall's discovery to pathology and practice, the value of which we leave to their own decision.

We close this biography with the feeling-with which we are sure our readers will rise from its perusal - of admiration of the industryøand professional devotion, as well as the talents, of Dr. M. Hall; for we must remember, that in the midst of all this investigation and publication, he has been engaged in active practice as a physician, and in the arduous duties of a lecturer. To the Nervous System alone (as he has himself recently informed us, and as we have already mentioned) he has devoted, during about twenty years, no fewer than 25,000 hours, and an equal amount of time in practice, making in all upwards of eleven years of working days of twelve hours each! His life, during forty years, has been one of uninter. rupted labour in science, as well as in practice. Few, indeed, have so combined the scientific with the practical talent-the philosopher with the sheer practitioner of medicine. The maxim "Ars sine scientiâ esse non potest" has constantly been present to his mind.

\section{DR. CARPENTER'S PRIZE ESSAY ON TEETOTALISM.} To the Editor of 'THE LANCET.

SiR,-I cannot admit that your correspondent "Justus" has any right to expect an answer from me, to either of the three questions he has propounded. The first he might have solved for himself, by a comparison of the two productions he has brought together; to the second he might have found an answer in the terms of the advertisement ; and the third would not affect $m y$ credit, even if his insinuation of unfairness in the adjudication of the "Temperance Prize" could be sustained, but reflects upon the character of the adjudicators, which it is not for me to defend. As I quite agree with "Justus," however, that " the very suspicion or possibility of partiality should not be suffered to exist in such cases," and as I have no desire for reserve or concealment as to $\mathrm{my}$ own share in the transaction to which he refers, I have called the attention of Dr. Forbes to the letter of "Justus," and have requested him to take such notice of it as he might think fit. From the accompanying letter to myself, which he kindly allows me to make public, it will appear that

The Lancre reviewer of my essay, who so unhesitatingly declared the adjudication to have been wrong, or "Justus" himself, who insinuates as much, had been in the place of Dr. Forbes as one of the adjudicators, it would have made no difference in the award.

I must be permitted to add, that as those are usually found to be most ready to impute unworthy motives to others, who are themselves most influenced by them, I shall not again think it necessary to take notice of personal insinuations from an anonymous correspondent; although I am quite willing to afford such information as it may be in my power to give, to any one who may show his right to ask for it; or to discuss a scientific question with an opponent who can dissent from my scientific conclusions without calling in question my integrity.

London, July, 1850. I am, Sir, your obedient servant, William B. Carpenter.

(Copy.)

From Dr. Forbes to Dr. Carpenter.

Dear Carpenter,--Since receiving your note, I have looked at "Justus's" letter in THE LANCET, on the adjudication of the Temperance Prize. Although I think both you and I can afford to bear the burden of his imputations in tranquillity and silence, still, if you would like to have your younger shoulders relieved from any portion of them, you are welcome to any little help I may be able to give you. You must, however, bear this in mind,-that as this just man thinks it quite a matter of course that an arbitrator, or at least that $I$ should decide in favour of a friend, without regard to the merits of his work as compared with others,-he will probably not stick at the lesser matter of disbelieving what I write in your defence or my own. But that is his affair, not mine; perhaps I may be able to outlive his scepticism as well as his aceusation.

In the first place, then, your essay was not an expansion of your article in my Review ; it contained, I verily believe, less of that excellent paper than did several of the other essays sent in.* Stcondly. Your essay was not in your own handwriting, but apparently in the capital roundhand of a professed transcriber. So far, therefore, you seem to have endeavoured to keep the authorship concealed; although this precaution was not taken by (I think) several of the other competitors, - certainly not by Dr. Spencer Thomson, the author of the excellent paper which was prononnced second-best by the adjudicators.

In the third place, I really do not know whether my colleagues, Drs. Roupell and Guy, are sufficiently acquainted with your " modes of thought and style of writing" to have detected you under your disguise, as it is insinuated that I could do, or did; but as you have given your enemies the advantage of having "written books"-and books widely read too-I think it not very improbable that some suspicions of authorship may have crossed the minds of the arijudicators. But he this as it may, I can, at least, testify to the fact, that if any such suspicions existed, they were never mentioned, or even hinted at in the remotest degree, during our examination of the essays, nor, so far as I know, have they been since. And even supposing that I had entertained the suspicion, or even had had positive knowledge of the authorship, and had consequently (and as a matter of course, according to our "Justus's" code of ethics) given my roice in your favour, it is clear enough that my corrupt vote would not have been the turning-point on which you were to receive the prize,-since my colleagues were both equally decided in awarding the prize to the essay which turned out to be yours. 'This essay would, therefore, have obtained the prize, even if my knowledge of the authorship had led me corruptly to vote against it, instead of for it.

But after all, the only question of the least importance in this matter is, whether, out of the fifteen essays submitted to their judgment, the arbitrators did really decide in favour of the best. If they did so, it matters very little what their suspicions or conjectures as to the authorship may have been. Now, I do not doubt that my excellent colleagues feel, with me, very easy on this point; and have not much fear that any tribunal of competent judges would come to a different conclusion, were the essays to be submitted to its adjudication.

I hope, therefore, my good friend, you will continue to wear your laurels peacefully, at least, if not proudly; feeling as little the imputation of having got them unworthily, as I feel the charge of having given them corruptly. But I am really ashamed to have written so gravely and at so much length on such a subject; and must now conclude.

Believe me, dear Carpenter, yours always, Old Burlington-street, July, 1850. JoHN FORBES.

* Dr. Spencer Thomson's published essay contains numerous and long quotatious from it.-W. B. C. 